\title{
A Simultaneous-Equation Model of Estimating Exchange Rate Pass- Through in Malaysia
}

\author{
Yu Hsing \\ Department of Management \& Business Administration, College of Business, Southeastern Louisiana University, USA
}

\begin{abstract}
Based on an extended IS-LM-AS model, this study finds that a $1 \%$ depreciation of the Malaysian ringgit tends to cause the CPI to rise by $0.1194 \%$. Moreover, more M2 money supply, a lower government borrowing as a percent of GDP, a higher crude oil price, a higher U.S. CPI, and a higher expected consumer price index tend to raise Malaysia's CPI. Therefore, exchange rate passthrough (ERPT) to the consumer price in Malaysia is partial and incomplete.
\end{abstract}

Keywords: Exchange rate pass-through, exchange rates, consumer prices, money supply, crude oil prices

\section{Introduction}

The impact of exchange rate depreciation or appreciation on domestic prices has been a concerned subject. During the Asian financial crisis, the exchange rate measured as units of the Malaysian ringgit per U.S. dollar changed from 2.57 in 1997.M7 to 4.41 in 1998.M1, indicating that the value of the Malaysian ringgit declined $71.60 \%$ versus the U.S. dollar during this time period. However, the consumer price index changed little during the same period. During the global financial crisis, the exchange rate changed from 3.16 in 2008.M4 to 3.67 in 2009.M3, suggesting that the ringgit depreciated $16.14 \%$. In response, the CPI rose $3.24 \%$. These examples suggest that consumer prices may not closely follow the change in the exchange rate. Large depreciation of the Malaysian ringgit is expected to raise import prices, wholesale prices, and consumer prices. It is an empirical question as to how the consumer price would react to the depreciation of the Malaysian ringgit.

To the author's knowledge, few of previous studies have applied and extended the IS-LM-AS model in studying ERPT to consumer prices in Malaysia. This paper has several different aspects. First, the paper uses an extended ISLM-AS model incorporating the exchange rate in the money demand function. Second, in the aggregate supply function, external shocks represented by the exchange rate and the energy cost are considered. Third, comparative static analysis is employed to determine how exchange rate movements would affect the equilibrium price level.

\section{Literature Survey}

Several recent studies have examined ERPT to prices for Malaysia and related countries. Applying the vector autoregressive model and using Malaysia's annual sample during 1980 - 2006, Ahamd (2009) finds that ERPT follows the distribution chain from import prices, to producer prices and then to consumer prices and that ERPT for Malaysia is estimated to be 0.18 in the long run. Hence, ERPT to consumer prices is relatively low and incomplete.

Applying the SVAR model to selected East Asian and Latin American countries and Turkey, Ito and Sato (2007) examined ERPT to prices after the Asian financial crisis. They found that ERPT is stronger in Turkey and the Latin

\footnotetext{
* Corresponding author.

E-mail address: yhsing@selu.edu (Yu Hsing)
} 
American countries than in East Asian countries except for Indonesia. Credible monetary policy would reduce ERPT to prices. Transmission from the import or producer price to the consumer price is pretty large in Indonesia, Mexico and Turkey. For Malaysia, ERPT to the consumer price is found to be 0.02 in the first quarter and 0.00 in 12 quarters, suggesting that ERPT to the CPI is relatively small and incomplete.

Ito and Sato (2008) applied the VAR model to estimate ERPT for five selected Asian countries including Malaysia after the Asian financial crisis. ERPT to import prices was relatively high whereas ERPT to consumer prices was relatively low except for Indonesia. For Malaysia, ERPT was estimated to be 0.03 to 0.005 in 12 months.

Using the VAR technique, Kohlscheen (2010) examined ERPT to consumer prices for eight countries with floating exchange rate systems. He found that ERPT is greater for countries trading more homogeneous goods and with higher exchange rate volatility. ERPT after one year ranges from a low of 0.09 for the Philippines to a high of 0.60 for Indonesia.

Prasertnukul, kim and Kakinaka (2010) investigated the effect of inflation targeting on ERPT for four selected Asian countries. For South Korea, ERPT to the CPI declines from 0.150 before adopting inflation targeting to 0.076 after adopting inflation targeting in the long run. For Thailand, ERPT to the CPI is found to be 0.124 in the long run and remains unchanged before and after adopting inflation targeting.

Saha and Zhang (2013) evaluated ERPT for Australia, China and India using the VAR model during 1990-2011. They found that ERPT to consumer prices is less in China and India than in Australia, that the depreciation of the yuan and rupee causes domestic price inflation, and that external variables have little impact on domestic prices in China and India, but interest rates, producer prices and industrial production effect their domestic prices.

Using the vector autoregressive model with exogenous variables for six emerging countries, Aleem and Lahiani (2014) studied ERPT to domestic prices. ERPT tends to be lower in countries with a more credible monetary policy, in Asian countries than in Latin American countries, and after the adoption of inflation targeting. ERPT became smaller after the adoption of inflation targeting in all six countries.

Based on a sample of nineteen high and middle countries, Dilla, Achsani and Anggraeni (2017) examined whether the adoption of inflation targeting (IT) would affect ERPT to the consumer price. The results are mixed. There was a significant difference of the long-run impacts of ERPT before and after IT between middle-income and high-income countries. The adoption of IT after financial crises led to more price stability in middle income countries. ERPT to prices declined in Indonesia and Thailand after the adoption of IT.

Using a sample of 15 emerging economies including Malaysia during 1994-2015, López-Villavicencio and Mignon (2017) assessed the impacts of inflation, inflation targeting and transparency of monetary policy on ERPT to prices. According to the findings, the adoption of inflation targeting results in a substantial decrease in ERPT; more transparency of monetary policy also leads to a declining ERPT; and a less volatile and a more anti-inflationary environment reduce ERPT.

Applying the SVAR model, Anh, Quan, Phuc, Chi and Duc (2018) examined ERPT to the CPI and PPI for five ASEAN countries including Malaysia. For Malaysia, ERPT to the CPI is 0.02 in the first quarter and 0.02 in the 8th quarters, and ERPT to the PPI is 0.18 in the first quarter and 0.14 in the $8^{\text {th }}$ quarter, suggesting that ERPT to the PPI is stronger than the CPI. Variance in the CPI is mainly caused by shocks to the oil price, the lagged CPI, the output gap, and the lagged PPI. Shocks to the interest rate and exchange rate play minor roles.

Assessing ERPT in six selected Asian countries including Malaysia during 1980.Q1 to 2014.Q3, Soon, Baharumshah, and Wohar (2018) found evidence of ERPT to the consumer price if inflation volatility is greater than 4.1725. The extent of ERPT varies because of low and high inflation volatility in non-inflation and inflation targeting countries.

Based on a sample of forty-seven countries including Malaysia, Ha, Stocker and Yilmazkuday (2019) indicated that ERPT to inflation differs across countries over time depending on the factors causing exchange rate changes and country characters. Those countries adopting credible inflation targets and flexible exchange rate systems have smaller pass-through ratios. More central bank autonomy helps to stabilize inflation and make the exchange rate as a cushion against external shocks. 
Examining ERPT for selected Asian countries including Malaysia during 1995.Q1-2016.Q4 and employing the nonlinear ARDL method, Kassi, Sun, Ding, Rathnayake and Assamoi (2019) showed that there is an asymmetric ERPT to prices in Asian developing countries in the short run and in Asian emerging countries in the short and long run, that ERPT is higher for appreciation than depreciation in the long run, and that there is evidence of downward rigid price and weak competition. They also showed that ERPT has not declined in these Asian countries in the long run. If a currency appreciates (depreciates) $1 \%$, the consumer price would decline $0.9 \%$ (rise $0.5 \%$ ) in the long run. ERPT is higher in emerging Asian countries with lower inflation and price volatility than in developing Asian countries.

\section{The Model}

It is postulated that aggregate spending is determined by real income, government tax revenue, government spending, the real interest rate and the real exchange rate, that real money demand is a function of the nominal interest rate, real income and the nominal exchange rate, and that the price level is represented by an augmented expectations supply function where the price level is influenced by the expected price level, the output gap, the nominal exchange rate, and the energy cost. Extending the IS-LM-AS model (Romer, 2006), we have:

$Y=F\left[Y, T, G, R-\pi^{e}, \varepsilon\left(P^{*} / P\right)\right]$

$M / P=H(R, Y, \varepsilon)$

$P=A\left(P^{e}, Y-Y^{*}, \varepsilon, E\right)$

where:

$\mathrm{Y}=$ real GDP in Malaysia,

$\mathrm{T}=$ government taxes,

$\mathrm{G}=$ government spending,

$\mathrm{R}=$ the nominal interest rate,

$\pi^{e}=$ the expected inflation rate,

$\varepsilon=$ the nominal exchange rate measured as units of the Malaysian ringgit per U.S. dollar,

$\mathrm{P}^{*} \quad=$ the price level in the U.S.,

$\mathrm{P}=$ the price level in Malaysia,

$\mathrm{M}=$ the money supply,

$\mathrm{P}^{\mathrm{e}}=$ the expected price level,

$\mathrm{Y}^{*}=$ potential real GDP, and

$\mathrm{E}=$ the energy cost.

Assume that potential real GDP is a constant in the short run. Solving for the endogenous variables $\left(\mathrm{Y}, \mathrm{R}-\pi^{e}\right.$, and $\left.\mathrm{P}\right)$ simultaneously, we can obtain the equilibrium price level as:

$\bar{P}=\bar{P}\left(\varepsilon, M, G-T, E, P^{*}, P^{e}\right)$

The determinant of the Jacobian matrix is given by:

$|J|=\left[-\left(1-F_{Y}\right) H_{R}-F_{R} A_{Y} M P^{-2}+F_{P} H_{R} A_{Y}-F_{R} H_{Y}\right]>0$

The partial derivative of $\bar{P}$ with respect to $\varepsilon$ can be expressed as:

$$
\begin{array}{r}
\partial \bar{P} / \partial \varepsilon=\left[-H_{R} A_{\varepsilon}\left(1-F_{Y}\right)-F_{\varepsilon} H_{R} A_{Y}-F_{R} H_{Y} A_{\varepsilon}+F_{R} H_{\varepsilon} A_{Y}\right] /|J|>0 \text { if } H_{\varepsilon}<0 \\
<\text { or }>0 \text { if } H_{\varepsilon}>0 .
\end{array}
$$

Equation (6) shows that the sign of the first three terms in the numerator is positive whereas the sign of the last term in the numerator depends on the sign of $H_{\varepsilon}$. The exchange rate may influence real money demand through the substitution effect and the wealth effect (Arango and Nadiri, 1981). If the wealth effect is greater than the substitution effect in absolute values, the sign in equation (6) would be unclear. If the substitution effect is greater than the wealth 
effect in absolute values, the sign in equation (6) would be positive.

\section{Empirical Results}

The data were collected from the International Monetary Fund and the World Economic Outlook. The price level is represented by the consumer price index. The nominal exchange rate is measured as units of the Malaysian ringgit per U.S. dollar. The money supply is represented by M2 money measured in millions. $G-T$ is expressed as government borrowing as a percent of GDP. The crude oil price per barrel is selected to represent the energy cost. The U.S. consumer price index is chosen to represent the U.S. price. The expected consumer price index is represented by the lagged consumer price index.

Table 1 presents the estimated regression and related statistics. The GARCH process is employed in empirical estimation in order to correct for autoregressive conditional heteroskedasticity. The estimated coefficients in the conditional variance equation are significant at the $1 \%$ level. Approximately $99.81 \%$ of the change in the consumer price index can be explained by the six right-hand side variables. All the estimated coefficients are significant at the $1 \%$ or $5 \%$ level. The consumer price index in Malaysia is positively affected by the nominal exchange rate, M2 money, the crude oil price, the U.S. price level, and the expected price level, and it is negatively associated with government borrowing as a percent of GDP.

Specifically, if the exchange rate rises 1 unit, the CPI will increase by 3.1221. Based on the mean values, the elasticity is estimated to be 0.1194 , suggesting that a $1 \%$ depreciation in the Malaysian ringgit would lead to $0.1194 \%$ increase in the consumer price index. In comparison, the estimated ERPT to the consumer price in this paper is greater than the estimates found by Ito and Sato $(2007,2008)$ and Anh, Quan, Phuc, Chi and Duc (2018) but less than the estimates made by Ahmad (2009) and Kassi, Sun, Ding, Rathnayake and Assamoi (2019)

A 1 percentage point increase in the government borrowing-to-GDP ratio will cause the CPI to decline by 0.3409 . The negative coefficient may suggest a relatively strong crowding-out effect, causing consumption and investment spending to decline more than deficit-financed spending. A $\$ 1$ increase in the crude oil price will raise the CPI by 0.0292. When U.S. CPI rises 1 unit, Malaysia's CPI will increase by 0.1234 . If the expected price rises 1 unit, Malaysia's CPI will increase by 0.6917.

Table 1. Estimated regression of the CPI in Malaysia

\begin{tabular}{lcc}
\hline Variable & Coefficient & Probability \\
\hline Intercept & 3.5022 & 0.0237 \\
exchange rate & 3.1221 & 0.0000 \\
M2 money & $4.38 \mathrm{E}-06$ & 0.0000 \\
Government deficit/GDP ratio & -0.3409 & 0.0000 \\
crude oil price & 0.0292 & 0.0465 \\
U.S. consumer price index & 0.1234 & 0.0008 \\
expected CPI & 0.6917 & 0.0000 \\
R-squared & 0.9981 & \\
Adjusted R-squared & 0.9976 & \\
Akaike information criterion & 2.2394 & \\
Schwarz criterion & 2.7110 & \\
Sample period & $1990-2018$ & \\
Number of observations & 29 & \\
\hline
\end{tabular}

Notes: The CPI is the consumer price index. The exchange rate is measured as units of the Malaysian ringgit per U.S. dollar.

There are several possible reasons for relatively small exchange rate pass-through to consumer prices. Depreciation of 
the Malaysian ringgit tends to shift aggregate demand to the right and aggregate supply to the left. A higher price level tends to increase the demand for money and raise the interest rate. A higher interest rate tends to hurt private spending, shift aggregate demand to the left, and partially cancel out the rightward shift in aggregate demand due to the depreciation of the Malaysian ringgit. Exporters selling products to Malaysia may absorb part of the price increase in order to maintain the market share. Retailers may absorb part of the price increase in order to prevent sales from declining. Consumer spending on imports may constitute a small proportion out of total spending.

\section{Conclusions}

This paper has examined ERPT to consumer prices in Malaysia based on an extended IS-LM-AS model. In the simultaneous-equation model, the equilibrium consumer price index is determined by the nominal exchange rate, M2 money, government borrowing as a percent of GDP, the crude oil price, the U.S. consumer price index, and the expected consumer price index. The depreciation of the Malaysian ringgit, more M2 money, less government borrowing as a percent of GDP, a higher crude oil price, a higher U.S. consumer price index, and a higher expected consumer price index tend to cause Malaysia's consumer price index to rise. Exchange rate pass-through to consumer prices in Malaysia is relatively small.

There are several policy implications. First, the depreciation of the ringgit causes the consumer price to rise. Although ERPT to the consumer price is partial, chronicle depreciation of the ringgit tends to raise the consumer price and reduce household wealth and consumption spending. Second, the consumer price index is also affected by the money supply. Hence, the authorities may need to make sure that the growth rate of the money supply is consistent with the growth rate of real GDP in order to avoid high inflation. Third, external shocks such as crude oil prices and the U.S. consumer prices tend to affect Malaysia's domestic prices. The government may need to monitor changes in these prices in order to measure their impacts on Malaysia's domestic price level.

\section{References}

Ahmad, N. B. (2009). The dynamics of exchange rate pass-through into domestic prices in Malaysia. (Doctoral Thesis) International Islamic University of Malaysia.

Aleem, A., \& Lahiani, A. (2014). Monetary policy credibility and exchange rate pass-through: Some evidence from emerging countries. Economic Modelling, 43, 21-29.

Anh, V. T., Quan, L. T. T., Phuc, N. V., Chi, H. M., \& Duc, V. H. (2018). Exchange rate pass-through in ASEAN countries: an application of the SVAR model. Emerging Markets Finance and Trade, 1-14.

Arango, S., \& Nadiri, M. I. (1981). Demand for money in open economies. Journal of Monetary Economics, 7(1), 6983.

Dilla, S., Achsani, N. A., \& Anggraeni, L. (2017). Do inflation targeting really reduced exchange rate pass-through?. International Journal of Economics and Financial Issues, 7(3), 444-452.

Edwards, S. (2006). The relationship between exchange rates and inflation targeting revisited (No. w12163). National Bureau of Economic Research.

Ha, J., Stocker, M., \& Yilmazkuday, H. (2019). Inflation and exchange rate pass-through. The World Bank.

Ito, T., \& Sato, K. (2007). Exchange rate pass-through and domestic inflation: A comparison between East Asia and Latin American countries. Research institute of Economy, Trade and Industry, RIETI Discussion Papers, 7040.

Ito, T. \& Sato, K. (2008). Exchange rate changes and inflation in post-crisis Asian Economies: Vector autoregression analysis of the exchange rate pass-through. Journal of Money, Credit and Banking, 40(7), 1407-1438.

Karim, B., (2005) Exchange rate pass-through into import prices in developing countries: an empirical investigation. Economics Bulletin, Vol. 3 no.26 pp. 1-14. 
Kassi, D. F., Sun, G., Ding, N., Rathnayake, D. N., \& Assamoi, G. R. (2019). Asymmetry in exchange rate passthrough to consumer prices: Evidence from emerging and developing Asian countries. Economic Analysis and Policy, 62, 357-372.

Kohlscheen, E. (2010). Emerging floaters: Pass-throughs and (Some) New commodity currencies. Journal of International Money and Finance, 29, 1580-1595.

López-Villavicencio, A., \& Mignon, V. (2017). Exchange rate pass-through in emerging countries: Do the inflation environment, monetary policy regime and central bank behavior matter?. Journal of International Money and Finance, 79, 20-38.

Prasertnukul, W. Kim, D. \& Kakinaka, M. (2010). Exchange rates, price levels, and inflation targeting: Evidence from Asian Countries. Japan and the World Economy, 22(3), 173- 182.

Romer, D., (2006) Advanced Macroeconomics, 3rd edition. Boston: McGraw-Hill/Irwin.

Saha, S., \& Zhang, Z. (2013). Do exchange rates affect consumer prices? A comparative analysis for Australia, China and India. Mathematics and Computers in Simulation, 93, 128-138.

Soon, S. V., Baharumshah, A. Z., \& Wohar, M. E. (2018). Exchange rate pass-through in the Asian countries: does inflation volatility matter?. Applied Economics Letters, 25(5), 309-312.

Tunç, C. (2017). A Survey on exchange rate pass through in emerging markets. Bulletin of Economic Theory and Analysis, 2(3), 205-233.

Yilmazkuday, H. (2013). Inflation targeting, flexible exchange rates and inflation convergence. Applied Economics, 45(5), 593-603.

Yilmazkuday, H. (2015). Pass-through of trade costs to US import prices. Review of World Economics, 151(4), 609633. 